\title{
Etymology and Word Decoding
}

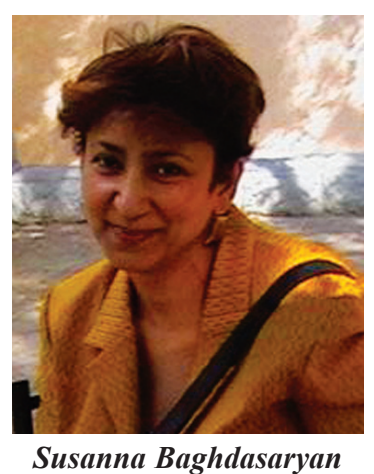

$T_{\text {rather than a list. Its elements interrelate and change }}^{\text {he vocabulary or lexicon of a language is a system }}$ subtly or massively from generation to generation. It increases through borrowing from other languages and through word-formation based on its own or borrowed patterns. It may decrease or increase in certain areas as interests change. Whole sets of items may vanish from general use and awareness, unless special activities serve to keep them alive.

Historically, the word-store of English is composite, drawn in the main from the Indo-European language family. The base is predominantly Germanic (mainly Old English and Old Norse) with a super-structure of Romance forms (mainly French and Latin) with a technical stratum contributed by Greek (mainly through Latin and French). In addition, there are many acquisitions from languages throughout the world.

The great number of borrowings gave way to the existence of the phenomenon bisociation in English, i.e. the occurrence in a language of pairs of words with similar meanings, one member of each pair being native to that language (such as everyday English sight), the other being a loanword from an influential foreign source (such as vision, a loanword from Latin). In English, the vernacular members of such pairs are mainly Germanic (usually from Old English or Old Norse), while the loanwords are mainly classical (usually from Latin, often mediated by French), as in: freedom/liberty, hearty/cordial, go up/ascend, go down/descend. Bisociation in English has often been remarked on. Simeon Potter, for example, observes: "We feel more at ease after getting a hearty welcome than after being granted a cordial reception" (Potter 1950:66). Similarly, Thomas Finkenstaedt has noted: "Apparently the Elizabethans discovered the possibilities of etymological dissociation in language: amatory and love, audition and hearing, hearty welcome and cordial reception" (Finkenstaedt 1973). This kind of semantic parallelism has also occurred in Latin, which has absorbed many words from Greek, creating such pairs as Latin compassio and Greek sympathia. In many instances, such pairs have passed into English, leading to trisociation, as with Germanic fellow feeling, Latinate compassion, and Greek-derived sympathy. There are scores of such correspondences in English, the Germanic material tending to be part of everyday usage (as with newness), the Latinate tending to be more formal and "educated" (as with innovate), and the Greek tending to be highly technical and even arcane (as with neophyte).

In fact a great part of the Latin and Greek borrowings doesn't form a part of our active vocabulary thus hindering their perception. However, it's impossible to escape the 
necessity of recognizing the latter since we often come across texts pertaining to different scientific domains. ${ }^{1}$

As it was mentioned above, the contact of English with various foreign languages has led to the adoption of countless foreign words and word parts. These parts were no doubt originally independent words. They came into English ready made and preserving their old meaning became suffixed or prefixed to full English words. There are many prefixes used in scientific terminology, which have come into the language through borrowings. These prefixes are still very productive, especially in scientific vocabulary and are used in scientific terminology. ${ }^{2}$

Prefixes or suffixes, or both are added to a root-form already in existence, and form a new word. These foreign affixes may be used with English roots. They make entirely new types unknown in the language from which they are adopted.

These affixes retain their original forms. As a consequence hybrid types of words are composed: a foreign word is combined with a native affix as in clearness or unbutton and a foreign affix with a native word as in breakage or growth.

Thus, one good approach is to learn how to build up or to tear apart words. A knowledge of these word parts and their meanings can help us to determine the meanings of unfamiliar words belonging to highly specialized areas of the vocabulary. For example the word amorphous which means shapeless according to Berger and Bowen can be divided into the following parts: a (without, not) and morph (shape, form) with the addition of the suffix ous (having the qualities of) (Berger, Bowen 2000:71).

Many other words such as bienniel or perennial can easily be differentiated by the meanings and by choice of affixes:

biennial-every two years $(b i=t w o$; enniel $=$ year $)$

perennial - present all year $($ per $=$ present; enniel $=$ year $)$

The role of the etymological factor in the analysis of English words (and not only English) is very important.

The result of our study is a list of common English and foreign prefixes, roots and suffixes that may come in handy. 


\begin{tabular}{|c|c|c|c|}
\hline Prefix & Meaning & Example & Illustration \\
\hline$a$ & without & amoral & without moral sense \\
\hline ante & before & antecedent & preceding event or word \\
\hline anti & against & antibody & against harmful bacteria \\
\hline auto & self & autobiography & $\begin{array}{l}\text { person's life written by } \\
\text { himself }\end{array}$ \\
\hline bene & good & beneficial & having good effect, helpful \\
\hline$b i$ & two & bicycle & two-wheeled vehicle \\
\hline circum & around & circumspect & to look around \\
\hline com & \multirow{5}{*}{ with, together } & combine & merge with \\
\hline Co & & coeditor & joint editor \\
\hline col & & collateral & connected \\
\hline con & & conference & meeting \\
\hline cor & & corroborate & confirm \\
\hline$D i$ & two & dichotomy & division into two parts \\
\hline dis & apart & disparity & condition of inequality \\
\hline hyper & above & hyperthermia & high temperature \\
\hline hypo & below & hypothermia & low temperature \\
\hline inter & between & interstate & between states \\
\hline mal & bad & malevolent & $\begin{array}{l}\text { wishing to do evil, bad to } \\
\text { others }\end{array}$ \\
\hline micro & small & microscopic & extremely small \\
\hline mis & wrong & mispronounce & to pronounce wrongly \\
\hline multi & many & multiplication & a given number of times \\
\hline neo & new & neophyte & beginner \\
\hline poly & many & polytheism & $\begin{array}{l}\text { worship of more than one } \\
\text { God }\end{array}$ \\
\hline re & again & redo & to do again \\
\hline retro & back & retrogress & to go or move backward \\
\hline se & away, aside & secede & withdraw \\
\hline semi & half & semiannual & every six months \\
\hline uni & one & unison & oneness of pitch \\
\hline tele & far & telemetry & $\begin{array}{l}\text { measurement from a } \\
\text { distance }\end{array}$ \\
\hline
\end{tabular}




\begin{tabular}{|c|c|c|c|}
\hline Root or stem & M e aning & Example & Illus tration \\
\hline agri & field & agrarian & one who works in the field \\
\hline alt & high & altitude & height \\
\hline anim & mind,soul & unanimous & of one mind \\
\hline bio & life & biology & study of living things \\
\hline celer & swift & accelerate & increase swiftness \\
\hline cord & heart & accord & agreement(from the heart) \\
\hline derm & skin & dermatology & study of skin \\
\hline ego & $I$ & egocentric & revolving about self \\
\hline fin & end,limit & confine & keep within limits \\
\hline gam & marriage & monogamy & marrage to one person \\
\hline domin & to rule & dominate & have power over \\
\hline helio & sun & heliotrope & flower that faces the sun \\
\hline labor & to work & laborious & difficult \\
\hline $\operatorname{leg}$ & law & legitimate & lawful \\
\hline $\operatorname{man}$ & hand & manuscript & written by hand \\
\hline mon & to warn & monitor & watcher, warner \\
\hline$n a v$ & ship & navigate & sail a ship \\
\hline omni & all & omniscient & all knowing \\
\hline path & desease & pathology & study of disease, tissue \\
\hline path & feeling & antipathy & hostile feeling \\
\hline psych & mind & psychopath & mentally ill person \\
\hline rupt & to break & interrupt & break into \\
\hline sect & cut & bisect & cut into two pieces \\
\hline somn & sleep & insomnia & inability to sleep \\
\hline term & end & interminable & endless \\
\hline urb & city & suburban & outside of city \\
\hline$v a c$ & empty & evacuate & compel to empty an area \\
\hline vol & wish & voluntary & of one's own will \\
\hline
\end{tabular}

\begin{tabular}{|l|l|l|l|}
\hline Suffix & Meaning & Example & Illustration \\
\hline able, ible & capable of & portable & able to be carried \\
\hline ary & like, connected with & dictionary & $\begin{array}{l}\text { book connected with } \\
\text { words }\end{array}$ \\
\hline ate & to make & consecrate & to make holy \\
\hline ation & that which is & irritation & annoyance \\
\hline fic & making, doing & terrific & arousing great fear \\
\hline ism & doctrine, belief & monotheism & belief in one god \\
\hline ity & state of being & annuity & yearly grant \\
\hline ive & like & expensive & costly \\
\hline oid & resembling & anthropoid & resembling man \\
\hline ose & full of & verbose & full of tears \\
\hline
\end{tabular}

Thus, by mastering basic word parts through etymology we will be able to unlock the meaning of numerous words. The list of foreign prefixes, suffixes, roots and stems may be several times as much as the above mentioned list but it is not unlimited. Whatever is within limit is not difficult to learn. Moreover, it is very interesting to go 
deeper into these studies enlarging our understanding of the vocabulary. "Learning thirty key word parts can help you unlock the meaning of over 10000 words. Learning fifty key word parts can help you unlock the meaning of over 100 000!" (Green 1998:242).

\section{Notes:}

1. This often results in serious problems in the teaching process as students sometimes have great difficulties in decoding scientific terms. Every word derives from its context and only the context will fix the exact meaning of the word which may be too vague or too ambiguous to make sense by itself. Sometimes the students succeed in figuring out a word's meaning by using their knowledge of context clues or by judging them, but very often they fail.

2. One of the commonest and also oldest methods of word-formation - derivation, is found in almost all languages and is considered a general linguistic phenomenon.

\section{References:}

1. Berger, L.; Bowen, H. (2000) Up your Score. The Underground Guide to the SAT. New York: Workman Publishing.

2. Finkenstaedt, Thomas; Wolff, Dieter (1973) Ordered Profusion. Studies in Dictionaries and the English Lexicon. Heidelberg: C. Winter.

3. Green, Sharon, Weiner; Wolf, Ira, K. (1998) How to Prepare for the SAT 1. Hauppauge: Barron's Educational Series.

4. Khidekel, S.; Ginzburg, R. (1975) Readings in Modern English Lexicology. Leningrad: Prosveshcheniye.

5. Kinneavy, James E.; Warrine, John E. (1998) Elements of Writing. New York: Holt, Rinehart \& Winston.

6. Potter, Simeon (1950) Our Language. England: Penguin Books.

7. www.encyclopedia.com

8. www.english-at-home.com

9. www.linguistics.ucla.edu

10. www.zas.gwz-berlin.de

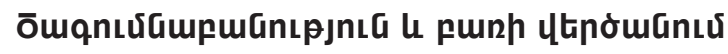

Ltiquh punmumz

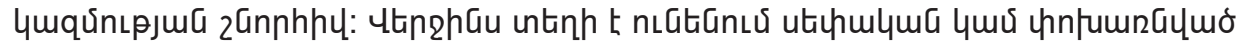

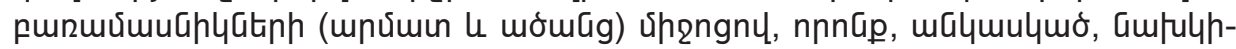

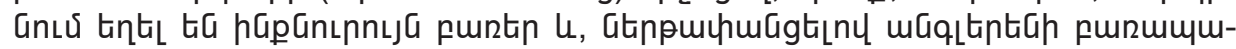

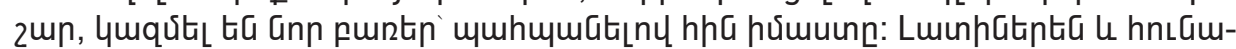

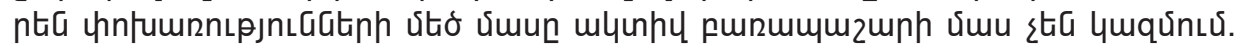

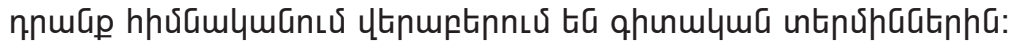

